\title{
Gerontology Counts: A Sociological Appraisal
}

ISSN: 2578-0093

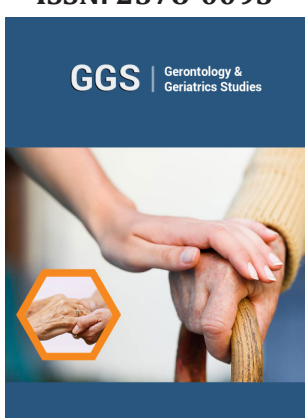

*Corresponding author: Mohammad TaghiSheykhi, Department of Sociology, Iran

Submission: 監 October 10, 2020

Published: 監 November 05, 2020

Volume 6 - Issue 3

How to cite this article: Mohammad TaghiSheykhi. Gerontology Counts: A Sociological Appraisal. Gerontol \& Geriatric stud. 6(3). GGS. 000636. 2020. DOI: $10.31031 /$ GGS.2020.06.000636

Copyright@ Mohammad TaghiSheykhi, This article is distributed under the terms of the Creative Commons Attribution 4.0 International License, which permits unrestricted use and redistribution provided that the original author and source are credited.

\author{
Mohammad TaghiSheykhi* \\ Department of Sociology, Iran
}

\section{Mini Review}

It is already obvious that due to the development of science and technology in different dimensions, a large number of people are getting aged in all parts of the world. Those countries which reached aging earlier, put the study of demography and gerontology on the agenda quite earlier. Such countries do not have many problems with their aging people. But, many countries in developing world that handled aging late, or not at all, are facing increasing problems with their aging people, i.e. their pensions, medications, housing and many more at the age of 65 and over. Such countries have not scientifically predicted their population on their move toward aging. In developing countries, the increasing aging people are living with shortfalls in their medications, livelihood, nursing, income etc.

Aging is emerging in $20^{\text {th }}$ and $21^{\text {st }}$ centuries more than any time before. Development in science, technology, medicine, food, clean water, and hygiene have widely helped in more human longevity. Through such series of development, people are experiencing longer life as compared with their ancestors. Many countries in developing countries do not yet have such experience as how to interact with the growing aging people. East, or broadly speaking, the developing world is unexpectedly facing new generations of the elderly people on the one hand, and the lowering of their youth below the age of 15 on the other hand. Despite the East, the Western countries have more experience in how to handle their aging people. Those countries have appropriately invested on research and practice in the field of biology, nursing, medicine, social work, public health, housing and anthropology for such people [1]. The nature of gerontology means that there are a number of sub-fields which overlap with gerontology. The developed countries entered the study of population aging quite earlier.

Due to their declining fertility rates and rising life expectancy, mostly the developed countries are facing more aging population. Aging population is an indicator of industrial countries. Social work plays a very prominent role to identify the status of aging people with special reference to those who are usually 65 and older. It functions quite better in the developed world countries, whereas in developing countries social work is not as developed, and because of that, many aging people are facing hazards of various kinds. Many aging people are afflicted with dementia and Alzheimer's disease disorders. Not only the Western scientists have written on aging and gerontology, but Avicenna also the Islamic scientist and researcher (1025) indicated the care of the aging people, including remedies, diet and constipation problems. The increasing number of the aged and life expectancy have started rising since the 14 th century, but with higher acceleration in recent centuries. The phenomenon has resulted in increasing many family issues. The term "gerontology" was first coined by Metchnikoff [2]. However, since 1940s National Institute on Aging started its activities at the University of Southern California [3]. People over 60 years old are predicted to be about 22 percent of the total population by the year 2050. Because of the age-related diseases the term the issues of aging people have been of priority with reference to treatment. As a demographic rule, baby-boomers of a time turn to aging population at another time. It is currently happening in Japan with 29 percent of aging people, Western Europe with 21 percent and the United States with 16 percent of aging 65 and over. Due to change and transition in science and technology, most parts of the world will face more elderly people in the next three decades [4-6]. So, geoscience needs to be used more to solve the issues emerging. Sex ratio is an indicator used in demography and gerontology. It indicates the number of males per 100 females. 


$$
\text { Sex Ratio }=\frac{\text { Males }}{\text { Females }} \times 100
$$

In industrial countries females outnumber males in in old ages.

\section{References}

1. Hooyman NR, Kiyak AH (2011) A Multidisciplinary Perspective: International Edition. In: ( $9^{\text {th }}$ edn), Social gerontology, UK.

2. Metchnikoff E (1903) The nature of man, studies in optimistic philosophy. Heinemann, London, UK.
3. NIA (2018) National Institute on Aging.

4. Burch JB, Augustine AD, Frieden LA, Hadley E, Howcroft TK, et al. (2014) Advances in geoscience: Impact on healthspan and chronic disease. Journal of Gerontology Series 69(Suppl_1): S1-S3.

5. Kohanski RA, Deeks SG, Gravekamp C, Halter JB, High K, et al. (2016) Reverse geroscience: How does exposure to early diseases accelerate the age-related decline in health. Annals of the New York Academy of Science 1386(1): 30-44.

6. Seeds DR, Justice JN, LaRocca TJ (2015) Physiological geroscience: targeting function to increase health span and achieve optimal longevity. J Physiol 594(8): 2001-2024. 